\title{
Reflections on the Politics of Professionalism: Critical Autoethnographies of Anti-Blackness in the ELA Classroom
}

\author{
Stephanie P. Jones \\ Grinnell College, jonesste@grinnell.edu \\ Robert P. Robinson \\ John Jay College of Criminal Justice, CUNY, rrobinson@jjay.cuny.edu
}

Follow this and additional works at: https://pdxscholar.library.pdx.edu/nwjte

Part of the Curriculum and Instruction Commons, Curriculum and Social Inquiry Commons, Language and Literacy Education Commons, Secondary Education Commons, and the Secondary Education and Teaching Commons

Let us know how access to this document benefits you.

\section{Recommended Citation}

Jones, Stephanie P. and Robinson, Robert P. (2021) "Reflections on the Politics of Professionalism: Critical Autoethnographies of Anti-Blackness in the ELA Classroom," Northwest Journal of Teacher Education: Vol. 16 : Iss. 2 , Article 13.

DOI: https://doi.org/10.15760/nwjte.2021.16.2.13

This open access Article is distributed under the terms of the Creative Commons Attribution-NonCommercialShareAlike 4.0 International License (CC BY-NC-SA 4.0). All documents in PDXScholar should meet accessibility standards. If we can make this document more accessible to you, contact our team. 


\title{
Reflections on the Politics of Professionalism: Critical Autoethnographies of Anti- Blackness in the ELA Classroom
}

\begin{abstract}
As Black educators, we are implanted with testimonies of how our pedagogies remained in close proximity to whiteness. We employ antiblackness and critical race theory frameworks. Through what we call vignettes of repair we address ourselves and our students to first, repair the harm we caused and second, to engage in collective witnessing that makes room for (re)claiming and (re)membering our own knowledge. From our critical reflection, we propose that teacher educators engage in a similar practice for their prospective teachers.
\end{abstract}

\section{Keywords}

Anti-racism, antiblackness, critical race theory, autoethnography, ELA, teacher education

\section{Creative Commons License}

cc) (1) (2)

This work is licensed under a Creative Commons Attribution-NonCommercial-Share Alike 4.0 International License. 


\section{Introduction}

Across the history of education in the United States, Black children have taken the brunt of local, regional, and national policies and practices whose main goal is to disenfranchise and dispossess them of educational rights and privileges (Dumas \& ross, 2016). Educational researchers have specifically named the ways antiblackness performs in schools including acts of curriculum violence (Jones, 2019) linguistic oppression (Baker-Bell et al., 2020) and unequal allotment of resources (Rothstein, 2014). Despite the evidence of how the institution of school works against Black and Brown children, there is a need for additional scholarship that speaks from the perspective of in-service teachers and teacher educators who speak directly to complicity. It is necessary to consider the ways the institution upheld antiblackness while also factoring in how teachers, regardless of intention, use it in our classrooms. This body of work inspires us to ask: Who did we, as teachers, want our students to become? How does the English classroom and curriculum make room for antiblackness? How do Black educators atone for and repair our (un)conscious alignment and approval of white cultural norms?

We ask these questions mainly because we understand that Black educators do not arrive neutrally to classroom teaching and learning contexts. In this paper, we seek to illuminate how antiblackness can infect what Black educators expect and demand from students.

Our entry point to this article is a result of us being former Black English teachers and current teacher educators. As we reflect on our times as in-service teachers, we are surrounded and implanted with testimonies - what it means to bear witness to how our pedagogies remained in close proximity to whiteness. As teacher educators at historically white institutions, we acknowledge the need to do this work, and it is imperative that we model the process for teachers.

In order to unpack these questions, we first frame our work under the lenses of antiblackness and critical race theory. We then discuss our research methods and rationale. Dr. Stephanie Jones opens with two vignettes about her experiences, and Dr. Robert Robinson continues with two vignettes about his-both uncovering the politics of antiblack respectability. We close with analysis of the vignettes and suggestions for teacher educators and early career teachers.

\section{Theoretical Framework}

Understanding antiblackness means understanding that Black personhood has been constructed as inhuman, expendable, and perpetually fixed as a problem. The origins of antiblackness in the United States begins with slavery and land theft, and since then the manifestations of antiblackness have remained intact in every institution since (Sharpe, 2016). One of those institutions, formalized education, has allowed antiblackness to flourish within classroom spaces, curriculums, and definitions of intelligence writ large. An expanding body of scholarship speaks to the ways in which antiblackness shows up in the lives of Black youth and their families (Dancy et al., 2018; Dumas, 2016; Dumas \& Nelson, 2016; Gholson \& Wilkes, 2017; Jones, 2019; King \& Woodson, 2017; Lyiscott, 2019; Mustaffa, 2017; Ohito, 2016; Parker, 2017; Thomas \& Warren, 2017; Warren \& Coles, 2020; Wun, 2016) and this article contributes to this knowledge through an autoethnographic glimpse from two Black educators. 
We position our work within the tradition of critical race theory (CRT) to challenge white classroom norms. CRT comprises six tenets: permanence of racism, whiteness as property, counter storytelling, interest convergence, critique of liberalism, and counter-storytelling (Capper, 2015). We pay specific attention to the tenets of intersectionality, whiteness as property, and the permanence of racism (Delgado \& Stefancic, 1993; Harris, 1993; Ladson-Billings \& Tate, 1995). Furthermore, we critique white norms and problematize the notion of "professionalism." By examining the intersections of race, class, gender, and sexuality, we recognize how white supremacy instituted our policing of Black and Brown bodies and conversations.

First, as it pertains to antiblackness, the permanence of racism under CRT is an important principle in our analysis. Whether it is conscious or unconscious (mostly the former), racism is at the foundation of the U.S. economic and social structure (Bell, 1992; Ladson-Billings \& Tate, 1995). The authors discuss how we attempted to help students mitigate the educational terrain using oppressive guidelines rooted in whiteness. In short, we attempted to use "the master's tools" to "dismantle the master's house" (Lorde, 2007). Whiteness itself is the logic of systems of power, leveraged as property. Even when we attempt to adhere to its norms as a means to gain power, our Blackness inherently negates those supposed protections. One of the many lessons that the BLM protests of 2020 retaught us is that property is always systemically valued over Black life. Mindful of this, we recognized the tenet of "whiteness as property" as the paradox of praxis that rendered our focus areas as counter-liberatory, even as we taught our students critical analysis approaches.

As a reconciliatory exercise, we employ vignettes as counter-story. According to education scholars counter-storytelling can operate "as a method of telling the stories of those people whose experiences are not often told" (Solórzano \& Yosso, 2002, p. 26). As Black educators, we acknowledge the harm committed, name the importance of our current liberation, and offer new understandings - for ourselves, our students, and those engaged in teaching and teacher education. While our words cannot undo the harm we caused, our speaking truth to power as "a sociopolitical critique," begins the restorative work necessary to Black liberatory education (Bell, 1992; Hill Collins, 2013; Solórzano \& Yosso, 2002, p. 32).

\section{Terms}

Respectability: According to historian Evelyn Brooks Higginbotham respectability politics placed an emphasis on "assimilationist leanings" that necessitated "conformity to the dominant society's norms of manners and morals" (Higginbotham, 1993, p. 187). This became conflicted ground as they leveraged these practices as battle against white supremacist notions of Black morality, even as they policed or "condemned" Black deflectors of these practices.

Professionalism: Draws upon assumptions about accepted codes or acceptable codes of practice in the workplace. Higginbotham argues that notions of respect and professionalism were leveraged by the women in her study. In the contemporary space, then, both respectability and professionalism derive from the same foundation: draw closer to whiteness by upholding antiblackness (Higginbotham, 1993, pp. 186$187)$. 
Antiblackness: Michael J. Dumas' work on antiblackness is informed by what he names as the "irreconcilability between the Black and any sense of social or cultural regard" (Dumas, 2016, p. 13). Antiblackness is not concerned with the eradication of slavery, but a full reckoning of the reality of Black life within a landscape of hatred and contempt.

\section{Methods}

Critical autoethnography is a qualitative method of inquiry that is centered on the self as a way to provide "nuanced, complex, and specific insights into particular human lives, experiences and relationships" (Holman Jones, 2018, p. 5). When we consider how sociocultural realities are imposed upon our personal lives, choosing a method that allows us to confront these realities is purposeful. Traditionally, autoethnography centers thick, rich descriptions of personal experience. Yet, those personal experiences cannot be fully fleshed out without the recognition and analysis of power. A critical autoethnography allows for personal stories to be told that explicitly point to our political positioning - how institutions and relationships of power work upon us and within us (Adams, 2017; Boylorn, 2016; Boylorn \& Orbe, 2014; Brown, 2020; Holman Jones, 2016).

How academic scholarship is typically structured, there should be a section for a literature review. Scholars scour what the research has said before, minding the gaps of where the research didn't fully take into account a component that could have changed the trajectory of the findings. While we provide background for the methods to understand what we are seeing, this reconciliatory act requires our voices, not those of professionals in the field. Nevertheless, we had to ask, "How can the literature review help us in our aim of repairing the harm done to Black children by their Black teachers?" This is our apology. And apologies require accountability, not references. Our commitment to Black children requires that we don't attempt to find their worth in the gaps of previous research, but that we name the harms that we have inflicted under the guise of good teaching.

\section{About the Vignettes}

Critical autoethnography allows us to examine our relationship as Black educators to the United States public school system. Within what we call vignettes of repair, critical autoethnography allows us to use these personalized stories to accomplish three goals: 1) we can problematize the relationship between the state's demands on Black and Brown children and how teachers are incentivized to enforce those demands. 2) allows us to use witnessing and counter-storytelling as a way to embody CRT. It is central that theory remains our metaphorical North Star while also connecting to the "people, places, and positions" that theory allows us to see more fully. 3) our vignettes speak to how the practice of accountability and repair can lead to a recognition of antiblackness ideologies, policies, and practices.

Each author presents two vignettes as examples of our practices of antiblackness in the ELA classroom. Jones begins the first vignette about antiblack regulations for attire at prom. She reflects on her complicity in upholding these rules and how it can impact how teachers expect students to experience a specific type of joy. Additionally, she reflects on what it means to guide students through high stakes graduation tests with questions rooted in antiblackness. Similar to Jones' first vignette, in his first vignette, Robinson also discusses the politics of attire with 
regards to classroom presentation rules. He outlines how the notion of professional attire is rooted in a white, middle-class belief about suitable workplace norms. Continuing in Jones' topic shift to language, Robinson discusses the antiblack distinction of colloquial speech and "academic language" in both his presentation prompts and writing assignments.

In terms of style, both authors employ italics to indicate the beginning of our vignettes. Our writing styles are both rooted in Black literacy traditions of plain speaking and writing. Whereas Jones' direct address reflects the spoken word, Robinson's reflects a form of Black correspondence. They are varied both in cadence and word choice, which illustrates the multiplicity of how we use Black language and pedagogical influences.

\section{Vignettes}

\section{Jones}

\section{Policing Black Joy}

I offer an autoethnographic response which doesn't claim to fill any holes, but rather insists on the naming of a complicity. To do this, I had to consider the way that I, a Black woman educator, exist for myself and also perform for others. It is worth repeating plainly: Crenshaw (1993) and Collins (2000) were right. Crenshaw taught us that race and gender don't fight for the top prize in oppression because Black women can't shed either of those identities for the other. Collins recognized that oppressions work in tandem with each other, interlocking and intertwining to the point where they operate independently. Black women can either be the mama everyone wants or the one everyone needs - and neither is where I want to be. In the schoolhouse, it's no different. The mammy and the matriarch also live in the expectations we have Black women teachers. Acosta (2019) outlines this in her study on Black women educators (BWE). She states that BWE "were expected to manage their own classroom", assume "responsibility for the difficult children", while labeled as "aggressive, masculine, and built to handle difficult school situations" (pg. 34). Black women teachers are exhausted, overlooked, and isolated.

The Friday before Prom was considered a "lost day of instruction." It was always an exciting time for all you who prepared. It was the social event of the year. Y'all saved, budgeted and dispersed money like the mightiest of financial experts. Your outfits were likely hanging in plastic bags over their closet doors and already booked appointments for fresh cuts and new acrylics. Sometime earlier that week, each homeroom teacher was given a list of instructions and rules for prom to read out to the students during homeroom. Because I attended prom as a chaperone for years, I wanted to make sure that I covered the other "unspoken" rules that I felt would protect the students and their investment.

I didn't write the rules, but I definitely read them aloud without objection or sarcasm. I remember that it included items such as details about parking and the time prom was scheduled to begin and end-important but not harmless right? Then, it started:

1. All prom dates are boy-girl.

2. No one over the age of 21 . 
3. No casual footwear allowed.

4. No hats.

5. Once you exit the Prom, you are not allowed to return.

It went on like this until at least 10 rules were displayed on the page. I read them as rules created out of a sense of protection. After all, I taught at "that" school. You know, free and reduced lunch, on that side of town, from that notorious apartment complex. The school's goal, and my goal was always about safety, never joy. And that was the framework in which I thought of every rule. Now could I see the limitation of my vision. The illusion of Black joy and safety was always wrapped in heteronormativity. The school didn't want to see queer Black children together. The school couldn't ban them from attending prom as individuals, but there was an attempt to regulate that love from ever becoming visible. The school demanded your respectability so much, they made it a rule. And I was silent.

Place matters when it comes to the ways in which to tell children what is respectable and how we define joy. I taught in Atlanta, in a city where Black folks had been running things for years. The city had a history of creating and cultivating Black people who went on to lead in the fight against global systemic racism. But I never considered the ways in which we procured the idea of safety in conjunction with respectability politics. What I didn't understand then is when they showed us images of our political leaders and clergy wearing suits and dresses, slacks and hats-that was their choice. They were in their groove by bringing contemporary fashion choices to the ever-present work of liberation. How it was sold to us and how I eventually sold it to you was to respect the sanctity of formality and tradition. This was a time to be professional and formal right? We used the same rhetoric on Dress for Success days at school. I thought that you needed to practice professionalism and in turn, you would feel better, and others would respect you more.

Scholar Michelle Smith uses the phrase respectability politics to describe the stance some marginalized people think about economic, political, and social progression. Progression happens not because the law demands it but rather due to a "compatibility with mainstream or 'non marginalized' class" (Smith, 2014). School spaces are not exempt from these types of political maneuvers and it is evidenced in how they regulate hair styles, haircuts, clothing and shoes. Frederick Harris (2014) describes these types of rules as "devised by Black elites, with the backing of the state and ordinary Blacks who believe in their efficacy" (p.33). Respectability existed before the United States elected its first Black president and because schools are constructed to uphold meritocratic narratives that align with 'anyone can become President,' Black children's bodies, even more so than before, are used as target practice for our imagination. One of the roots of antiblackness is the myth of meritocracy. This investment in the rhetoric of 'trying' despite the impact of antiblack structural systems upon our children, means that educators create new rules that are arbitrary and random. It doesn't matter the quality or quantity of these rules, antiblackness remains at the core of our need to control Black children and their joy.

You knew more about respect and joy than I did. You knew that being alive, being a high school student in the 2000's and 2010's meant showing off all of the contradictions of surviving a failed education system. Tuxedos were paired with 
clean, crisp Air Force Ones and fitted caps with 'A' embroidered on the front. Prom dresses were hand made by the community, showcasing the places where the school dress code couldn't be enforced for a few hours. Y'all wore sunglasses inside at night. The outfits were designed around belly rings, tattoos, customized dress colors in blue and orange. Even when y'all's feet got tired of walking around in heels, you already thought of the matching slippers. Imagine not being able to see this joy!

\section{High Stakes Antiblackness}

I was placed on the 11th grade team in my first year of teaching. I didn't know what that meant, but I soon discovered 11 th grade was full of all of the standardized tests. I took it almost as an honor that I would be the one to help students take and pass what was then called graduation tests. Each student had to take and pass five-Math, English Language Arts, Social Studies, Science and a timed writing essay. In addition to graduation exams, students were also responsible for end of course tests whose results counted for $15 \%$ of their overall grade.

On test days, we had to take butcher paper from the art classroom and cover up any material on the wall that would provide students with assistance on the test. You know, the posters describing what a noun and a verb is or the parts of a paragraph. I walked down each aisle and lightly touched every single one of you on the shoulder, hoping that you would know that I knew you could do it. I don't know if that worked at all, but I was excited to hear how you felt you did.

I would usually begin test prep about a month out. I was taught as a preservice teacher and through tons of professional development that I should never teach to the test. The components of the test should be embedded in my instruction and y'all should intrinsically pick up on "if we discussed metaphors in this story, I should be able to compare what we did in class with the metaphors in this passage"-Y'all told me that it don't work that way and I believed you. You told me that I couldn't use the lesson to allude to the test and that I should plainly say this was on the test. You knew our language better than I did and for me to speak directly was necessary and a sign of respect.

I remember telling you that there would be dumb questions on the test that wouldn't count. Even in the study packet provided by the state, I was tasked with preparing you to consider questions such as "what does 90 days same as cash mean?" This was American Literature, mind you. You got tripped up when they asked whether the subject verb agreement "I is or We be" counted as incorrect English or slang. I had to tell you how we speak among ourselves is cool, but how other folks thought about how we spoke mattered more.

I saw how the test was rigged to make us feel as if we were dumb. But most of my job was to help you feel smarter than the test projected you to be. I hate that no matter how well you did, the test still determined your grade in the class.

I do need to apologize for something else, however. Even though I talked shit during class about how the test is rigged and we are smart enough to see through it, I never questioned that truth outside of those walls, to the face of white folks. I was 
inconsistent. It used to be important to me that you all knew how much they hated our language but I also wanted you to comply. I wanted you to perform as I usually do and when you didn't -I was embarrassed. Looking back, I should have been prouder of you, and I should have told you that as much as possible.

\section{Robinson}

Dress for Success: Inculcation into Antiblack Notions of "Professional Attire"

As a firm believer in culturally relevant pedagogy, I sought to affirm student voices and perspectives and languages, and I tried to include diverse texts to represent the students who were before me (Ladson-Billings, 1994, 1995; Paris, 2012)). Nevertheless, in my attempt to prepare students for college, I employed a number of strategies that were rooted in whiteness, which is particularly harrowing for the Black students in my class who-like me-were well-versed in Black American English.

One manifestation of this practice was in my current events discussions. From $10^{\text {th }}$ grade to $12^{\text {th }}$ grade, I implemented Friday current events. Five students would choose a recent article that engaged questions of race, class, gender, sexuality, ability, and/or climate change; analyze the article; and facilitate a discussion for their peers. The second manifestation was in my reading response papers and formal essays. While the language of the text was "neutral" on the surface, my lenses aligned with deficit frameworks rooted in antiblackness.

Dear Class of 2011 and 2015,

I want to apologize for the ways I upheld white supremacy and antiblackness. First, I would like to apologize for how I discussed professionalism in our presentations, beginning during our current events cycles. As I prepared you for each semester's round of presentations, I opened with a sample text, and I demonstrated the analytical strategies. I then modeled a facilitated discussion with all of you. In my recollection, those discussions were rich, as we covered protests, global warming, the gender pay gap, affirmative action, antiblackness, and more. Nevertheless, I cannot help but consider the embedded contradiction between our discourse and my criteria for presentations.

Right now, no lie, I am cringing as I recall the ways I imposed standards of "professionalism." Each cycle of presentations, we reviewed the presentation rubric, and I explained what I meant by "professional attire." The exchange would often sound like this:

"Mr. Robinson, can we wear jeans?"

"Good question; I believe you can if you don't have slacks or khakis. Make sure they are black or dark denim, though. You sort of want to look like you're going in for a job interview."

"What does that look like?"

"Guys, you should have on a collared shirt, tie-if possible-let me know if you need to borrow one), khakis/slacks, and business casual shoes. Avoid tennis shoes if possible. Ladies, you should wear the same (tie is totally optional). If you wear a dress or skirt, make sure it's lengthier - mid-thigh/knee or longer. A nice plain blouse is fine. Also avoid tennis shoes."

"What if all we have is tennis shoes?"

"That's fine; just remind me before you present, so that I don't dock points." 
Here I was trying to teach you to think and work against the system, and I was reinforcing standards of "appropriate attire" linked to whiteness and middle-class norms. I am looking at our rubric for the class now with all its vague description for each grade: "Dressed professionally" for " $A$ "; "Dressed Appropriately" for "B"; "Casual Attire" for $C$, and "Dressed completely inappropriately" for a "D/F." Oddly enough, these were just a few points of the grade, not the entire score. And there was no explicit point tabulation for the rubric, so it was definitely open for interpretation. [See Attached Rubric]

Class of 2015, I owe you an even lengthier apology. During the spring semester of your sophomore year, I brought in a guest from the fashion college to discuss fashion as a potential career. I also asked him to speak on appropriate job interview attire. I really thought I was doing something. When I saw that he was a white man-probably in his early fifties-who wore oversized clothes with a dated tie, I should have already been cautious.

He urged even more conservative attire:

"No jeans at all. Keep the colors pretty basic: black, brown, navy, gray, and white. Men should wear pleated pants. Pants should fit, but they should not be too tight (skinny fit was in) or too baggy. Women should wear a pants suit or nice pants/skirt with a light-colored blouse."

Again, he and I had both reinforced a particular type of "professional" attire. The "dress for success" model was all aligned with respectability politics: "if you want people to take you seriously, you have to dress the part." Meanwhile, folks at Twitter and Google walk around in jeans and stained t-shirts with runover tennis shoes and teachers across campus wore myriad styles of clothing for their daily teaching attire. What was I trying to prove? To whom was I trying to prove it? In what ways had I not considered the dynamism of your clothing, of living life out loud as you are? I often told you that my role was to provide you access to power, but I am wondering if I was guilty of forcing you to assimilate into the existing power structure of whiteness so that you would be more palatable for white audiences. Your humanity wasn't relegated to what you wore but rather to your sheer existence; the burden was not on you to prove your worth but on the white world to recognize it.

\section{Talk that Talk: Antiblackness in Speaking \& Writing}

While I am here snitching on myself, I also want to apologize for how I punished Black linguistic complexity. For example, I often spoke to you in all of my voices, upholding "academic language" and Black Southern California English. I boldly told you how I came from Southeast, historically held as the Blackest part of the city. At the same time, I came to class wearing ties and using fancy terms. On a daily basis, I modeled how to employ the language spoken in college halls, even as I maintained the languages of my home life and of our "inner city" community-what scholar Ofelia Garcia refers to as "translanguaging” (Vogel \& García, 2017).

When it came to presenting, though, I heavily privileged a strong code-switch to the supposedly academic register. Once again, I am looking at the presentation rubric. In the category of "professionalism" I list several language identifiers. Under the criteria for an A, I noted "Used considerable amount of academic language" and "Did not use ANY colloquial speech (slang)." In the "B" criteria, I wrote "used some academic language" and "Used very little colloquial speech." "Used very little academic language" and "Used noticeable amount of colloquial speech" were in the 
$C$ criteria. In the D/F section, "No academic language" and "Mostly slang/inappropriate language" were the markers. While I boldly show up as myself now, I strongly discouraged you from showing up as your entire self, even in the way you spoke.

In terms of the reading responses, the language was much less explicit, at least on the surface. Nevertheless, I also found myself exercising punitive approaches when I saw an abundance of spelling, grammar, syntactical, or conventional "errors." Embedded in me was what —now considered old school-comedian Cedric The Entertainer referred to as the "wish factor": "I wish a mf would." This is most often the disposition a person uses when they are challenged subtly or blatantly by another person. If I am being honest with myself, I sometimes hoped-or "wished"one of y'all would cross that nine-error threshold, so I could stop reading and send the paper back for revision. That method works with a potential opponent, but it does not maintain the most supportive relationship between the writing teacher and student. I used the supposedly neutral or objective language of the rubric to reinforce norms, which had the unintended but still very real effect of killing some students' spirits.

A few years ago, I wrote a short essay describing how being closeted hindered me from showing up in all the ways I wanted to-for me-for you. Even as I verbally affirmed you all, the shame I felt for myself trickled into the work I did (Robinson, 2020). From 2011, James, a young Black man in our cohort, often moaned, "Mr. Robinson be snakin'." In the next cohort from 2015, Leonard could be heard repeating the same refrain: "Mr. Rob stay snakin' on my reading responses." I was a Black man overly penalizing Black teenage boys in the name of rigor-trapped between wanting to provide access to higher education and wanting you to show up as yourselves. I encouraged you to keep yourselves hidden as a means of navigating the white world, and I apologize.

Remember how I kept the "Language is Power" sign in the classroom? I would often say that as your language arts teacher, my job was to give you access to language, so that you could leverage it for power. At the time, I thought the comment was fire. Perhaps it would have been if the implied language I was referring to was not what white mainstream education has established as standard academic English. Maybe I would have been a better support if I told you to embrace all of who you are-if I told you how the white world would judge you for your linguistic choices but that this did not mean you always had to subscribe to their standards. I drilled in you the same difficult dance I had to navigate in my daily life. Now as I find my voice, I wonder how much more I could have served you if I brainstormed acts of refusal that embodied the same criticality I tried to teach in our textual analysis.

\section{Implications and Conclusion}

As painful as this reflective exercise was, it also operated as a site for healing. Through internal conversations, writing, and dialogue with each other, the authors reckoned with our own complicity with antiblack practices as a springboard for further Black liberatory praxis. By naming our stories through critical autoethnographic vignettes of direct address, we also foregrounded the CRT tenet of counter-storytelling (Bell, 1992; Solórzano \& Yosso, 2002). This act of repair does not absolve us of our past harm; the damage has been done. Nevertheless, it does serve as an act of restoration, as we attempt to know and do better for Black students. 
In our analysis of clothing, we were forced to see how school dress codes and our own guidelines and notions of professionalism were rooted in respectability that also maintained antiblackness and heteropatriarchy (Higginbotham, 1993). As we reinforced "acceptable attire" in our respective schools, we limited student creativity and freedom. Just as late 19th and early 20th race men and women leveraged these practices of respectability and professionalism to affirm our humanity in the face of white supremacy, we inherited and wielded this double-edged sword of antiblackness that severed our ties to Black creativity in language and dress.

Nevertheless, while Jones recalled the policing embedded within prom guidelines, she also highlighted student attire rooted in a politics of what Jabari Asim refers to as "strutting." Black youth recognized the power of their own prom choices. According to Asim, "Freed from the default gaze, strutting is more likely to reflect the enchanting intelligence of human beings who know their power and maybe even revel in it" (Asim, 2018, p. 38). These politics of strutting-sometimes conflated with notions of Black respectability — suggests a form of showing up and showing out for one's own shine within a Black community. Moreover, the practice alludes to a long history in Black American aesthetics of "Sunday's Best," Zoot suits, early $21^{\text {st }}$ century "stuntin'," or today's "drip" (Banner \& Brown, 2008; Birdman \& Lil Wayne, 2006; Cardi B \& Migos, 2018).

These clothing accounts provide at least two implications for teachers: 1) An opportunity to understand how notions of professionalism or appropriateness in dress reinforce racial and economic hierarchies - and thus an opportunity to avoid this practice 2) Students' own articulations of dress speak to their own lineage of drip that should be honored.

Our language practices also reinforced violence that privileged white language standards. Jones discussed how she adhered to evaluative norms within standardized testing. While she recognized students' brilliance and multiple literacies and invited them to critique "rigged" standardized tests in class, whispers of white supremacy induced shame during her personal reflections and interactions with colleagues.

Similarly, Robinson employed Black English in his day-to-day interactions with students, but his presentation rubrics and internalized writing structures privileged white notions of professionalism and academic language that pervade language arts discourse. Rather than celebrate students" "full linguistic repertoire" (Paris, 2012; Vogel \& García, 2017), he urged them to participate in code-switching which leverages whiteness as the standard.

These critical reflections highlight 2020's “This Ain't Another Statement! This is a DEMAND for Black Linguistic Justice!" (Baker-Bell et al., 2020). The list of demands assert that "socially constructed terms such as academic language and standard English are false and entrenched in notions of white supremacy and whiteness that contribute to anti-[b]lack linguistic racism" (2020, Demand 1). Mindful of this, as reflective education scholars and teacher educators, we the authors further affirm the demand that "teachers develop and teach Black Linguistic Consciousness that works to decolonize the mind (and/or) language" (Demand 4). In practice, this means creating reading, writing, listening, and speaking spaces that honor Black students' Black English and BIPOC students' linguistic practices in general. Teachers should name and critique linguistic hierarchies and the role they play in society as they simultaneously honor students' languages and allow them the choice of their practices in the classroom. 
The ELA classroom becomes a critical space for this type of work for a number of reasons, but namely two: 1) It is one of the few courses that is required all four years of high school 2) Language is power-and as teachers of language, English teachers have immense potential to reinforce and reproduce harm, or disrupt linguistic violence and counter linguistic hegemony. By countering our own collusion with white supremacy, we highlight how we were indoctrinated in teacher education spaces that were training grounds in antiblackness.

As Black professors we now embody our entire Black selves in our research and pedagogy. Nevertheless, we still had to engage in the excavation work to see our complicity with antiblackness. If we must turn the gaze inward in order to refine our contemporary praxis, white and non-Black pre-service teachers, in-service teachers, and teacher educators must be even more vigilant if all of us are committed to affirm and value Black lives in the $\mathrm{K}$ through university classroom.

\section{Notes On The Contributors}

Stephanie P. Jones, PhD. is an Assistant Professor of Education at Grinnell College. Her two research strands examine Black women's literacy practices and the exploration of racialized trauma in school curriculums. She is part of the inaugural cohort of Associated Colleges of the Midwest Mellon Faculty Fellows, a STAR fellowship recipient through the Literacy Research Association and she serves as Grinnell College's Center for the Humanities Fellow for 2021-2022. She is working on a forthcoming manuscript about the intersections of surveillance, curriculum violence, and racialized trauma.

Robert P. Robinson is an Assistant Professor in the SEEK Program at John Jay College and an Induction Mentor at Teachers College, Columbia University. His broad research and teaching focus on Black education history, history of U.S. education, curriculum studies, higher education mentorship, and the Black Freedom Movement. His primary research project is a history of the Black Panther Party's Oakland Community School (OCS) as a site for understanding Black selfdetermination, the shift in mainstream curriculum and pedagogy, and the Black radical imagination in education. 


\section{References}

Acosta, M. M. (2019). The paradox of pedagogical excellence among exemplary Black women educators. Journal of Teacher Education, 70(1), 26-38. https://doi.org/10.1177/0022487118808512

Adams, T. E. (2017). Critical autoethnography, education, and a call for forgiveness. International Journal of Multicultural Education, 19(1), 79-88. https://doi.org/10.18251/ijme.v19i1.1387

Asim, J. (2018). We can't breathe: On black lives, white lies, and the art of survival.

Baker-Bell, A., Williams-Farrier, B. J., Jackson, D., Johnson, L., Kynard, C., \& McMurty, T. (2020,). This ain't another statement! This is a DEMAND for Black linguistic justice! Conference on College Composition and Communication. https://cccc.ncte.org/cccc/demand-for-black-linguistic-justice

Banner, D., \& Brown, C. (2008). Get Like Me (Stuntin' is a Habit). https://genius.com/David-banner-get-like-me-lyrics

Bell, D. (1992). Faces at the bottom of the well: The permanence of racism. BasicBooks.

Birdman, \& Lil Wayne. (2006). Stuntin' Like My Daddy. https://genius.com/Birdmanand-lil-wayne-stuntin-like-my-daddy-lyrics

Boylorn, R. M. (2016). On being at home with myself: Blackgirl autoethnography as research praxis. International Review of Qualitative Research, 9(1), 44-58. https://doi.org/10.1525/irqr.2016.9.1.44

Boylorn, R. M., \& Orbe, M. P. (2014). Critical autoethnography: Intersecting cultural identities in everyday life. Left Coast Press.

Brown, D. V. (2020). Self-structure singularity: Considerations for agential realism in critical psychology. Social and Personality Psychology Compass, 14(12), e12569. https://doi.org/10.1111/spc3.12569

Capper, C. A. (2015). The 20th-year anniversary of critical race rheory in education: Implications for leading to eliminate racism. Educational Administration Quarterly, 51(5), 791-833. https://doi.org/10.1177/0013161X15607616

Cardi B, \& Migos. (2018). Drip ft. Migos. https://genius.com/Cardi-b-drip-lyrics

Collins, P. H. (2000). What's going on?: Black feminist thought and the politics of postmodernism. Working the Ruins, 41-73.

Crenshaw, K. W. (1993). Beyond racism and misogyny: Black feminism and 2 live crew. Words That Wound., 111-132.

Dancy, T., Edwards, K., \& Davis, J. (2018). Historically white universities and plantation politics: Anti-Blackness and higher education in the Black lives matter era. Urban Education, 53, 176-195. https://doi.org/10.1177\%2F0042085918754328

Delgado, R., \& Stefancic, J. (1993). Critical race theory: An annotated bibliography. Virginia Law Review, 79(2), 461-516. https://doi.org/10.2307/1073418

Dumas, M. J. (2016). Against the dark: Antiblackness in education policy and discourse. Theory Into Practice, 55(1), 11-19. https://doi.org/10.1080/00405841.2016.1116852

Dumas, M. J., \& Nelson, J. D. (2016). (Re)Imagining Black boyhood: Toward a critical framework for educational research. Harvard Educational Review, 86(1), 27-47. https://doi.org/10.17763/0017-8055.86.1.27

Dumas, M. J., \& Ross, K.K. (2016). "Be real Black for me": Imagining BlackCrit in education. Urban Education, 51(4), 415-442.

https://doi.org/10.1177/0042085916628611 
Gholson, M. L., \& Wilkes, C. E. (2017). (Mis)Taken identities: Reclaiming identities of the "collective Black" in mathematics education research through an exercise in Black specificity. Review of Research in Education, 41(1), 228252. https://doi.org/10.3102/0091732X16686950

Harris, C. I. (1993). Whiteness as property. Harvard Law Review, 106(8), 1707-1791. https://doi.org/10.2307/1341787

Harris, F. (2014). The rise of respectability politics. Dissent Magazine. https://www.dissentmagazine.org/article/the-rise-of-respectability-politics

Higginbotham, E. B. (1993). Righteous discontent: The women's movement in the Black baptist church, 1880-1920. In Fulcrum.org. Harvard University Press.

Hill Collins, P. (2013). On intellectual activism. Temple University Press.

Holman Jones, S. (2016). Living bodies of thought: The "critical" in critical autoethnography. Qualitative Inquiry, 22(4), 228-237. https://doi.org/10.1177/1077800415622509

Holman Jones, S. (2018). Creative selves/creative cultures: Critical autoethnography, performance, and pedagogy. In S. Holman Jones \& M. Pruyn (Eds.), Creative selves / creative cultures: Critical autoethnography, performance, and pedagogy (pp. 3-20). Springer International Publishing. https://doi.org/10.1007/978-3-319-47527-1 1

Jones, Stephanie. (2019, November 25). Ending curriculum violence. Teaching Tolerance. https://www.tolerance.org/magazine/spring-2020/ending-curriculumviolence

King, L., \& Woodson, A. (2017). Baskets of cotton and birthday cakes: Teaching slavery in social studies classrooms. Social Studies Education Review, 6, 118.

Ladson-Billings, G. (1994). The dreamkeepers: Successful teachers of African American children. Jossey-Bass Publishers.

Ladson-Billings, G. (1995). But that's just good teaching! The case for culturally relevant pedagogy. Theory into Practice, 34(3), 159-165.

Ladson-Billings, G., \& Tate, W. F. (1995). Toward a critical race theory of education. Teachers College Record, 97(1), 47-68. http://search.proquest.com.ezproxy.gc.cuny.edu/docview/61403332/D5FC48E696E1 $48 \mathrm{~A} 2 \mathrm{PQ} / 2$

Lorde, A. (2007). Sister outsider: Essays and speeches (Revised edition..). Crossing Press.

Lyiscott, J. (2019). Black appetite. white food.: Issues of race, voice, and justice within and beyond the classroom. Routledge.

Mustaffa, J. B. (2017). Mapping violence, naming life: A history of anti-Black oppression in the higher education system. International Journal of Qualitative Studies in Education, 30(8), 711-727. https://doi.org/10.1080/09518398.2017.1350299

Ohito, E. O. (2016). Refusing curriculum as a space of death for Black female subjects: A Black feminist reparative reading of Jamaica Kincaid's "Girl." Curriculum Inquiry, 46(5), 436-454. https://doi.org/10.1080/03626784.2016.1236658

Paris, D. (2012). Culturally sustaining pedagogy. Educational Researcher, 41(3), 93 97. https://doi.org/10.3102/0013189X12441244

Parker, L. (2017). Schools and the no-prison phenomenon: Anti-Blackness and secondary policing in the Black lives matter era. Journal of Educational Controversy, 12(1). https://cedar.wwu.edu/jec/vol12/iss1/11 
Robinson, R. P. (2020). A new diagnosis: Rethinking normativity. In Key concepts in curriculum studies: Perspectives on the fundamentals (pp. 151-152). Routledge.

Rothstein, R. (2014). The racial achievement gap, segregated schools, and segregated neighborhoods - A constitutional insult. Economic Policy Institute.

https://www.epi.org/publication/the-racial-achievement-gap-segregated-schools-andsegregated-neighborhoods-a-constitutional-insult/

Sharpe, C. E. (2016). In the wake: On Blackness and being. Duke University Press.

Smith, M. (2014). Affect and respectability politics. Theory \& Event, 17(3). https://muse.jhu.edu/article/559376

Solórzano, D. G., \& Yosso, T. J. (2002). Critical race methodology: Counterstorytelling as an analytical framework for education research. Qualitative Inquiry, 8(1), 23-44. https://doi.org/10.1177/1077800402008001003

Thomas, E. E., \& Warren, C. A. (2017). Making it relevant: How a Black male teacher sustained professional relationships through culturally responsive discourse. Race Ethnicity and Education, 20(1), 87-100. https://doi.org/10.1080/13613324.2015.1121217

Vogel, S., \& García, O. (2017). Translanguaging. Publications and Research. https://academicworks.cuny.edu/gc_pubs/402

Warren, C. A., \& Coles, J. A. (2020). Trading spaces: Antiblackness and reflections on Black education futures. Equity \& Excellence in Education, 53(3), 382398. https://doi.org/10.1080/10665684.2020.1764882

Wun, C. (2016). Unaccounted foundations: Black girls, anti-Black racism, and punishment in schools. Critical Sociology, 42(4-5), 737-750. https://doi.org/10.1177/0896920514560444 


\section{Appendix}

\section{Presentation Rubric}

\begin{tabular}{|c|c|c|c|c|}
\hline Category & $\mathbf{A}$ & B & $\mathbf{C}$ & $\mathbf{D} / \mathbf{F}$ \\
\hline Professionalism & $\begin{array}{l}\text { *Dressed professionally } \\
\text { *Used considerable } \\
\text { amount of academic } \\
\text { language } \\
{ }^{*} \text { Stayed on topic } \\
{ }^{*} \text { Did not use ANY } \\
\text { colloquial speech (slang) }\end{array}$ & $\begin{array}{l}{ }^{*} \text { Dressed appropriately } \\
{ }^{*} \text { Used some academic } \\
\text { language } \\
{ }^{*} \text { Mostly on topic } \\
\text { *Used very little } \\
\text { colloquial speech }\end{array}$ & $\begin{array}{l}\text { *Casual Attire } \\
\text { *Used very little } \\
\text { academic language. } \\
\text { *Strayed from topic } \\
\text { once } \\
\text { *Used a noticeable } \\
\text { amount of colloquial } \\
\text { speech. }\end{array}$ & $\begin{array}{l}\text { *Dressed completely } \\
\text { inappropriately } \\
\text { *No academic } \\
\text { language } \\
\text { *Strayed from topic } \\
\text { often/off-topic } \\
\text { *Mostly } \\
\text { slang/inappropriate } \\
\text { language }\end{array}$ \\
\hline Clarity/Volume & $\begin{array}{l}\text { *Spoke loudly } \\
\text { *Pronounced words well } \\
\text { *Enunciates every word }\end{array}$ & $\begin{array}{l}{ }^{*} \text { Audible } \\
{ }^{*} \text { Pronounced most words } \\
\text { well. } \\
\text { *Enunciated the majority } \\
\text { of words }\end{array}$ & $\begin{array}{l}{ }^{*} \text { Barely audible } \\
{ }^{*} \text { Mispronounced some } \\
\text { words. } \\
{ }^{*} \text { Little enunciation }\end{array}$ & $\begin{array}{l}\text { *Nearly inaudible } \\
\text { *Mispronounced } \\
\text { many words } \\
\text { *Very little } \\
\text { enunciation }\end{array}$ \\
\hline Eye-Contact & $\begin{array}{l}\text { *Looked at classmates } \\
\text { frequently when speaking } \\
\text { or reading aloud }\end{array}$ & $\begin{array}{l}{ }^{*} \text { Made eye contact often } \\
\text { when speaking or } \\
\text { reading aloud }\end{array}$ & *Made little eye contact & $\begin{array}{l}\text { *Made eye contact } \\
\text { once or twice }\end{array}$ \\
\hline $\begin{array}{l}\text { Engagement/ } \\
\text { Energy/Presence }\end{array}$ & $\begin{array}{l}\text { *Energetic. Good pacing } \\
\text { *Calm yet assertive } \\
\text { *Engaging \& interesting } \\
\text { * Appropriate tone and } \\
\text { dynamic presence }\end{array}$ & $\begin{array}{l}\text { *Somewhat energetic. } \\
\text { Decent Pacing } \\
{ }^{*} \text { Somewhat assertive } \\
\text { *Mostly engaging } \\
\text { *Shifts in tone }\end{array}$ & $\begin{array}{l}{ }^{*} \text { Lacking connection. A } \\
\text { bit too fast or too slow } \\
\text { *A little fidgety } \\
\text { *Made an attempt to } \\
\text { engage audience } \\
\text { *Some energy }\end{array}$ & $\begin{array}{l}\text { *Dull/Lifeless. Drawn } \\
\text { out or too short } \\
\text { *Very fidgety } \\
\text { * Did note engage the } \\
\text { audience at all } \\
\text { *Monotone }\end{array}$ \\
\hline
\end{tabular}

